\title{
Redefining the Status of the Librarian in Higher Education
}

\section{Bill Crowley}

Progress in the study of the role, function, and status of the academic librarian requires system-level analysis. Drawing on the field of higher education, this article seeks to avoid "individual blame" controversy through focusing on membership norms for the academic system and its librarian subsystem. Changes in the librarian subsystem are being advocated by influential higher-education theorists. Unless librarians secure peer status through adherence to core academic standards, the emerging era of electronic information will see a diminution in the librarian's influence over library affairs.

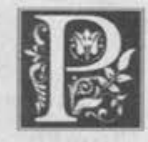

roductive exchanges over certain core aspects of the role, function, and status of the librarian within higher education are becoming increasingly more difficult to sustain. An almost tangible fatigue, resulting from years of intradisciplinary dispute over educational requirements, a perception of professional marginalization, and a discerned future of resource scarcity, seems to have negatively affected discourse in this critically important area. ${ }^{1}$ In her 1990 dissertation on the professional identity of librarians in American higher education, Jacquelin Marie Page addressed the emotions generated by the issue. ${ }^{2}$ Recognizing the personal unpleasantness that her research might evoke, Page avoided direct contact with academic librarians. Instead, she limited her information gathering to the content analysis of library school catalogs and job advertisements. The author's 1995 inquiry involved the status of librar- ians within research universities and drew responses ranging from the clearly reasoned to the explosively emotional. Passion by itself is no bar to inquiry; the vehemence of some of the replies to the author's American and Canadian surveys actually advanced his research effort. ${ }^{3}$ Nonetheless, much will be lost if researchers, concerned about the sensitivity of the topic, forswear investigations fundamental to understanding the place of the librarian within the academy.

Library and information science researchers have asserted that progress within the profession on critical issues often depends on outside intellectual assistance. ${ }^{4}$ In the specific case of academic libraries, the advantages are obvious: academic libraries are components of larger institutions. To study the forces that affect a college or university is to consider factors that affect its library. A second argument for calling on the resources of other fields and disciplines is the self- re-

Bill Crowley works in the Office of the President Emeritus at Ohio University, Athens; e-mail: crowley@ouvaxa.cats.ohiou.edu. He wishes to express his appreciation for both reviewers and editorial assistance. 
flective character of research within library and information science. In this context, Jeffrey N. Gatten found a failure to make use of insights drawn from other specialties and disciplines. ${ }^{5}$ This inadequacy is not unique to library and information science. Levels of intellectual insularity affect virtually all disciplines and many research questions.

Higher education is a field focused on the realities of the academic enterprise. As such, it represents a critical resource for the study of university and college libraries. In 1985, George Keller reported that scholars trained in economics, psychology, politics, history, and sociology regularly contribute to the analysis of higher-education issues. ${ }^{6}$ Collectively, such research makes the higher-education literature extraordinarily useful for librarians with an interest in the perceptions of faculty and administrators.

Since the 1960 s, a specific field of study called "higher education" has developed, now taught at some one hundred American and four Canadian institutions. Admittedly, most of the scholarship and opinion produced by this enterprise are ignored by academic presidents, deans, and other practitioners. Notwithstanding, the collective literature of higher education provides an excellent guide to the biases and truths that dominate the academic system. In this context, it can serve as a rich resource for those attempting to interpret, and perhaps improve, the academic subsystem inhabited by the librarian. ${ }^{7}$

Of particular concern to the study of the status of the librarian within higher education are the following questions:

1. What are the characteristics of the academic system?

2. What are the characteristics of the library subsystem?

3. Do the characteristics of the academic system differ significantly from the characteristics of the library subsystem?
4. What, if anything, can or should be done about any differences between the academic system and the library subsystem?

At a future date, this researcher intends to provide an assessment of the place of the academic library in the Canadian system of higher education. The present analysis concentrates on the place of the library and librarian within the American academy.

\section{Characteristics of the Academic System}

The sheer size and complexity of American higher education confounds most efforts at generalization. In 1994, The Carnegie Foundation for the Advancement of Teaching identified 3,595 providers of higher education in the United States. ${ }^{8}$ Given the number and variety of colleges and universities listed by the Carnegie Foundation, full review of the American system of higher education and its librarian subsystem threatens a multivolume work. Fortunately, a useful replacement can be constructed through utilization of the higher-education phenomenon known as "upward drift." Briefly, upward drift is the historic tendency for community colleges to grow into four-year colleges, for teachers colleges to become universities, and for universities to increasingly emulate the Universities of Michigan or California. Given this pattern for development, the future of the American academy can often be discerned through review of innovations currently being implemented in its elite institutions. Descriptions drawn from observations of these eighty-eight $\mathrm{Re}$ search Universities I and thirty-seven Research Universities II inevitably represent an amalgam of biases, perceptions, and facts. Burton R. Clark, in The Academic Life: Small Worlds, Different Worlds, described the system as consisting of hierarchies and miniworlds, where research dominates teaching, and institutions and departments vie in a never-ending search 
for prestige and power. ${ }^{9}$ It is a society where the teaching/research faculty and administration abide in precarious balance. Within the system, administrators guide, cajole, and reward through the allocation of tangible resources. Intangible rewards, such as praise and proclamations of ideological community, also are employed but with less effect. Particularly in the sciences, higher education is a competitive "culture of credit," torn between collaborative ideals and the contest for influence and government grants. ${ }^{10}$

Within departments, the research university is an environment where the goals of prestige in a discipline, institutional tenure, and the prerequisites of a full professorship are paramount. These are achieved through research renown, an adequate level of teaching effectiveness, appropriate institutional service, and the intense cultivation of senior faculty. It is the habitat of "The Ph.D. Octopus" and "The Ph.D. Squid." " It is also a well-established system where would-be participants put personal lives on hold for the years of study and research necessary to earn a doctorate. With increasingly rare exceptions, the Ph.D. and its equivalents are required of all players in the competitive arenas found at the heart of America's leading academic institutions. Unless compensated for through extraordinary achievement in another context, lack of a doctorate equals life on the periphery of the research university.

\section{Characteristics of the Library Subsystem}

The condition of academic libraries on the eve of the twenty-first century is well documented in the library and information studies literature. ${ }^{12}$ Continued restrictions in funding and multiplying demands by scholars for access to electronic information are common to most accounts. In a response to the author's 1995 surveys, one library educator-whose confidentiality was guaranteed as a condition of reply-as- serted in an e-mail message of January 31, 1995, that:

the reality facing academic libraries today ... is one of budgetary cutbacks and financial constraint. The literature is full of how research universities are struggling to cope with this reality - staff cuts and serials cancellations are two of the major ways. Organizational restructuring in academic libraries has resulted in flattening the managerial hierarchy.

In a 1987 essay in the American Scholar entitled "Libraries and Learning," the historian Oscar Handlin described research libraries as fighting a losing battle to maintain collection comprehensiveness in a world dominated by hyperspecialists and narrow research interests. ${ }^{13}$ Among the problems Handlin saw were the waste of resources on purchasing little-used material and the loss of the library information monopoly because of the availability of information in electronic formats. Judging research library efforts to maxi-

With increasingly rare exceptions, the Ph.D. and its equivalents are required of all players in the competitive arenas found at the heart of ... leading academic institutions.

mize use of scarce resources through collaboration and automation, Handlin concluded that salvation did not lie with either approach. He also saw librarians as central to the travails of the academic research library. Chief among the sins ascribed to librarians was a willingness to align "with presidents, deans, and provosts and too readily acquiesce in budgetary constraints." In addition, librarians "are also excessively vigilant, on guard against interference by users whom they too often treat as adversaries rather than as allies." 


\section{Differences in Academic System and Library Subsystem Characteristics}

The sociologist Robert K. Merton described subgroups as "structurally constituted by those who develop distinctive social relations among themselves which are not shared with members of the larger group. All groups are potentially vulnerable to such sub-group formations." ${ }^{14}$ For the purposes of this exploration, Merton's remarks on groups and subgroups hold for academic systems and subsystems.

Exploring the differences between the academic system and the library subsystem requires an ability to recognize reality in unguarded moments. Burton $\mathrm{R}$. Clark described academic power as involving "delicate fictions" and "ambiguous definitions," while stressing that "deans and provosts have enough to do without deliberately stirring up trouble for themselves." ${ }^{15}$ The use by administrators of both tangible and intangible assets has already been noted. Indeed, one might profitably study rhetorical support for the library ("heart of the university") in the context of administrative strategies for maintaining morale in a period of resource scarcity. ${ }^{16}$

Occasionally, academic leaders will reveal a more equivocal perception of the librarian to nonlibrary audiences. Jacques Barzun, former dean of faculties and provost of Columbia University, tended to be supportive in the library press. His admonition that "scholars should be librarians and librarians should be scholars" is fairly well known. ${ }^{17}$ Less familiar to the profession may be his evaluation of the librarian's status in The American University: How It Runs, Where It Is Going. ${ }^{18}$ In this major work, Barzun, writing as a higher-education theorist, termed librarians and journalists "intellectual middlemen" who confused "the assembling of items found here and found there" with true research.

Characterizing librarians as "intellectual middlemen" tends to add to a campus climate that overlooks their contri- butions. But such mild disparagement usually lacks direct consequences for budgets and personnel rosters. More serious are forceful assertions that librarians do not possess the intellectual competence to manage library affairs.

In 1985, Frank Newman, president of the Education Commission of the States, authored Higher Education and the American Resurgence, an influential Carnegie Corporation Special Report. ${ }^{19}$ This work argued that libraries need to move from an emphasis on acquiring materials to accessing them wherever they are located, an assertion in accord with contemporary library theory. However, Newman avowed that academic librarians lack the capability to direct their institutions in a new electronic world. He stated:

Library personnel, while now fully competent to handle the library automation that has taken place, have neither the education nor the emotional commitment to prepare for the shift in outlook required to change from owning, cataloging, and lending, to becoming electronic data sleuths ready to link a student or faculty member to someone else's data bank. Moreover, the time has come for information specialists [nonlibrarians] to learn more about the needs of the library. ${ }^{20}$

In light of such assertions, placement of academic libraries under associate provosts or vice presidents for information services represents more than administrative realignment. From a system-based perspective, it is a logical step in a process through which the academic system will assume more control over matters formerly left to the library subsystem. Although the occasional appointment of librarians to associate provost or vice president positions is to be welcomed, such developments do not minimize the reality of the changes being implemented. For the academic system, the provision 
of electronic information to faculty scholars now has new significance. As such, it will not be left to a subsystem whose dissimilar educational standards and variant operational norms complicate administrative and faculty understanding.

\section{Addressing the Differences between the Academic System and the Library Subsystem}

Discussions of differences between the academic system and the library subsystem inescapably involve consideration of the doctorate. This inevitability arises from the fact that the doctorate is a symbol that subsumes such other factors as research and teaching, even as it offers a possible basis for cooperation between librarians and teaching faculty. To illustrate the complexities involved, the author edited a defense of the librarian-asmanager from a response to his 1995 surveys. His intent was to compare the position of library director with that of education dean. The respondent wrote:

I differ strongly with your statement that [library] administrators [College of Education Deans] should have a $\mathrm{PhD}$. It has never been proven satisfactorily that the doctoral degree is a prerequisite for effective leadership, vision, or even operational management. The primary function of a library director [College of Education Dean] is to lead, innovate, and advocate; it is no longer necessary (and in fact it never was necessary) to have $\mathrm{ahD}$ to certify to the faculty that one understands their needs and can translate those needs into effective services and resources. ${ }^{21}$

Within the library subsystem, a doctorate is not required by subsystem norms. This fact is demonstrated by the substantial number of directors without doctorates in the ARL. ${ }^{22}$ However, lack of a doctorate is a serious problem within the larger academic system. Even in the relatively low-status field of education, the prospect of a dean substituting a master's degree and management experience for a Ph.D. or Ed.D. degree verges on the incomprehensible. Deans frequently oversee multimillion dollar budgets and substantial personnel. Yet, particularly in areas related to the curriculum, deans are expected to have both administrative experience and the doctorate.

Research in communications and information diffusion suggests an additional complication for a master's degree subsystem within a doctoral structure. With such disparity in educational levels, the potential for communication effectiveness is markedly diminished. Charles A. Schwartz argued that "academic librarians are strategically situated to be the main agents of electronic development of
Although the occasional appoint- ment of librarians to associate provost or vice president positions is to be welcomed, such developments do not minimize the reality of the changes being implemented.

the scholarly information system."23 However, studies of the diffusion of information, and the faculty's own possessiveness regarding communication within disciplines, suggest otherwise. It is simply unrealistic to plan for a future where the teaching faculty cede such authority to librarians, unless librarians are viewed by faculty as peers or near-peers within the academic system.

Before considering whether the library subsystem should adopt the educational standards of the parent system, it is necessary to understand why librarians operate with required qualifications so different from those of the teaching faculty. From a system point of view, it appears that the subsystem developed along lines that limit the 
doctorate as a resource for career advancement.

In a 1995 article entitled "The Opportunity Costs of Faculty Status for Academic Librarians," Bruce R. Kingma and Gillian M. McCombs examined the conditions necessary for librarians to maintain faculty status. ${ }^{24}$ They defined opportunity costs as costs that "represent the opportunities the individual or agency must forgo to achieve the desired output, although they include the actual dollar costs."

As noted elsewhere by Robert J. Branham:

The concept of opportunity cost is one of fundamental importance to the fields of economics and policy analysis.... Benefits sacrificed from the best available alternative constitute the true cost of any action, and therefore should be at the center of all policy disputes..$^{25}$

Unlike the overwhelming majority of teaching/research faculty at research universities, new academic librarians are not required to have a doctorate in hand at the time of appointment. Employment and promotion within the library subsystem require a master's degree from a program accredited by the ALA and, eventually, a subject master's degree. ${ }^{26}$ There is little incentive for a librarian to devote the three to seven years of study necessary to earn a doctorate. The opportunity costs that count against doctoral

\section{Bluntly stated, in a time of restricted resources and costly technological opportunities, libraries have a more visible status.}

study, including actual expenses, years of lost income, and full or partial withdrawal from the competition for internal or external promotions, simply outweigh the advantages gained. It is a matter less of individual preference than of subsystem imperatives. The library subsystem sets the rules of the competition; intelligent players work the rules to their advantage. The library subsystem, with programmed regularity, thus sustains educational and other norms that differ substantially from those of the teaching faculty.

The general tenor of responses from academic library directors analyzed by the author in his 1995 study indicates an inability or unwillingness to align librarian educational standards with the norms of the academic system. A number of respondents cited a perceived inapplicability of the doctorate to library operations, a humanistic preference for collaborative work within the library over competition within the departments, and a lack of funding for adequate salaries as barriers to libraries meeting the educational criteria of the parent academic community. These same responses demonstrated general concern over the impact of financial constraints on library services. More specifically, academic library directors struggled with the effects of restricted funding for staff on the academic library's ability to meet growing faculty demands for electronic resources. To address these issues, the library directors stressed the need for increased funding from academic administrators and sought to develop in their staff the highest possible levels of electronic information expertise. ${ }^{27}$

From a system point of view, increased funding and enhanced electronic expertise, though clearly needed, represent technical solutions for a problem colored by conflict between system and subsystem values. ${ }^{28}$ Bluntly stated, in a time of restricted resources and costly technological opportunities, libraries have a more visible status. Complaints about defects in academic library services, as documented in the higher-education literature and face-to-face discussions between administrators and faculty, have an impact on academic decision makers. 
Problems in library subsystem operations, not just the amounts of library budgets, now command attention. Under the revised understanding governing electronic information access, either the library subsystem will negotiate a transformed relationship with the academic system or administrators following after Frank Newman will impose a revised relationship on the library.

Reshaping of the library subsystem by the parent academic system is now under way. The point under debate is whether the library subsystem will be an active participant in its own transformation. One method of testing the ability of the library subsystem to remake itself would be a formal reexamination of the value to librarians of the doctorate, the fundamental criterion for membership in the academic system. A first step in such a debate would be a proposal to require future directors of university libraries to possess a doctorate as a condition for institutional membership in ARL. Such a debate, although beginning with a specific issue, would provide an unmatched forum for exploring other areas where the library subsystem deviates from the academic system as a whole. If this doctoral requirement is actually adopted, there should be sufficient lead time to enable ambitious librarians to adjust their calcu- lations of opportunity costs to fit new subsystem norms.

Arguably, adoption by the ARL of the requirement of a doctorate for university library directors will move academic librarianship as a whole toward the norms of the higher-education system. In this context, the working of "upward drift" within the academy should be recalled. Over time, doctoral qualifications for library directors at the research university would encourage similar changes at other levels of higher education.

It is a sociological and communications truism that subjective perceptions have real consequences. What is believed to be real is often more important than reality itself. ${ }^{29}$ Regardless of what academic librarians know about their actual value to faculty and administrators, the literature of higher education consistently portrays librarians as ancillary to the academic enterprise. In a period of restricted resources, higher education is being urged to develop priorities even among the teaching and research disciplines. ${ }^{30}$ Without a recognized claim to peer status and comparable treatment when resources are allocated, librarians will increasingly find life on the academic periphery to be no life at all as the hard decisions on funding and personnel are made.

\section{Notes}

1. See Edward G. Holley, "Defining the Academic Librarian," College \& Research Libraries 46 (Nov. 1985): 462-68; Irene B. Hoadley, Sheila Creth, and Herbert S. White, "Reactions to 'Defining the Academic Librarian,'" College \& Research Libraries 46 (Nov. 1985): 469-77; and Allen B. Veaner, "Paradigm Lost, Paradigm Regained? A Persistent Personnel Issue in Academic Librarianship, II," College \& Research Libraries 55 (Sept. 1994): 389-402. A summary of the results of various studies of faculty perceptions of the librarian may be found in Robert T. Ivey, "Teaching Faculty Perceptions of Academic Librarians at Memphis State University," College \& Research Libraries 55 (Jan. 1994): 69-82.

2. Jacquelin Marie Page, "The Pursuit of Professional Identity for Librarianship within American Higher Education: A Study of Educational Programs and Work Requirements in Socialization for Academic Identity in the 1980s" (Ph.D. diss., Saint Louis University, 1990), 249-61.

3. William A. Crowley Jr., "A Draft Research Model of the Research University Library: Exploring the Scholar Librarian Partnership of Jaroslav Pelikan in The Idea of the University: A Reexamination" (Ph.D. diss., Ohio University, 1995), 125-56, 217.

4. See Charles R. McClure and Peter Hernon, eds., Library and Information Science Research: Perspectives and Strategies for Improvement (Norwood, N.J.: Ablex Publishing, 1991). 
5. Jeffrey N. Gatten, "Paradigm Restrictions on Interdisciplinary Research into Librarianship," College \& Research Libraries 52 (Nov. 1991): 575-84.

6. George Keller, "Trees without Fruit: The Problem with Research about Higher Education," Change 17, no. 1 (Jan./Feb. 1985): 7-10.

7. See Association for the Study of Higher Education, ASHE Membership and Higher Education Program Faculty Directory (College Station, Texas: ASHE, 1995); James L. Bess, Foundations of American Education: An ASHE Reader (Needham Heights, Mass.: Ginn Pr., 1991); Keller, "Trees Without Fruit," 7-10; and Lee M. Wolfle, "Prestige in American Universities," Research in Higher Education 18 (1983): 455-72.

8. The Carnegie Foundation for the Advancement of Teaching, A Classification of Institutions of Higher Education, 1994 ed. (Princeton, N.J.: The Carnegie Foundation for the Advancement of Teaching, 1994).

9. Burton R. Clark, The Academic Life: Small Worlds, Different Worlds (Princeton, N.J.: The Carnegie Foundation for the Advancement of Teaching, 1987).

10. Jon Cohen, "The Culture of Credit," Science 268, no. 5218 (23 June 1995): 1706-11.

11. See William James, "The Ph.D. Octopus," in Memories and Studies (New York: Greenwood Pr., 1968), 329-47; Paul D. Isaac, Stephen V. Quinlan, and Mindy M. Walker, "Faculty Perceptions of the Doctoral Dissertation," Journal of Higher Education 63 (May/June 1992): 241-68; A. Clay Schoenfeld and Robert Magnan, Mentor in a Manual: Climbing the Academic Ladder to Tenure, 2d ed. (Madison, Wisc.: Magna Publications, 1994); and Theodore Ziolkowski, "The Ph.D. Squid," American Scholar 59 (spring 1990):177-95.

12. See Richard M. Dougherty and Ann P. Dougherty, "The Academic Library: A Time of Crisis, Change, and Opportunity," Journal of Academic Librarianship 18 (Jan. 1993): 342-46; Richard M. Dougherty and Carol Hughes, Preferred Futures for Libraries: A Summary of Six Workshops with University Provosts and Library Directors (Mountain View, Calif.: Research Libraries Group, 1991); Eldred Smith, The Librarian, the Scholar, and the Future of the Research Library (New York: Greenwood Pr., 1990); and Eldred Smith and Peggy Johnson, "How to Survive the Present While Preparing for the Future: A Research Library Strategy," College \& Research Libraries 54 (Sept. 1993): 389-96.

13. Oscar Handlin, "Libraries and Learning," American Scholar 56 (spring 1987): 218.

14. Robert K. Merton, Social Theory and Social Structure, rev. and enl. (New York: Free Pr., 1968), 341 .

15. Clark, The Academic Life, 150-52.

16. See Mary Biggs, "Sources of Tension and Conflict Between Librarians and Faculty," Journal of Higher Education 52 (Mar./Apr. 1981):182-201; Rebecca Kellogg, "Beliefs and Realities," College \& Research Libraries News 47 (Sept. 1986): 492-96; Robert F. Munn, "The Bottomless Pit, or the Academic Library as Viewed from the Administration Building," College \& Research Libraries 50 (Nov. 1989): 635-37. Reprinted from College \& Research Libraries (Jan. 1968): 51-54; and Paul Olum, "Myths and Realities: The Academic Viewpoint I," College \& Research Libraries 45 (Sept. 1984): $362-66$.

17. Jacques Barzun, "The Scholar Looks at the Library," College \& Research Libraries 7 (Apr. 1946): 116. See also Jacques Barzun, "The New Librarian to the Rescue," Library Journal 94 (1 Nov. 1969): 3963-65.

18. Jacques Barzun, The American University: How It Runs, Where It Is Going, $2 \mathrm{~d}$ ed. (Chicago: Univ. of Chicago Pr., 1993), 198.

19. Frank Newman, Higher Education and the American Resurgence (Princeton, N.J.: The Carnegie Foundation for the Advancement of Teaching, 1985).

20. Ibid., 152.

21. Crowley, "Draft Research Model of the Research University Library," 196-97.

22. Marcia J. Myers and Paula T. Kaufman, "ARL Directors: Two Decades of Changes," College \& Research Libraries 52 (May 1991): 241-54. Determination of how lower educational standards for directors "diffused" within the ARL membership requires an extended-and wellfinanced-analysis of the composition of candidate pools, the deliberative processes of search committees, and the motivations of university provosts and presidents. As such, it is beyond the scope of this consideration.

23. Charles A. Schwartz, "The Strength of Weak Ties in Electronic Development of the Scholarly Communications System," College \& Research Libraries 55 (Nov. 1994): 530. An essential, if aging, summary of the librarian's role in scientific communications is found in William D. Garvey, Communication: The Essence of Science (Oxford: Pergamon Pr., 1979), 126. For summaries of research on information/innovation diffusion, see Everett M. Rogers, Diffusion of Innovations, 4th ed. (New York: Free Pr., 1995). 
24. Bruce R. Kingma and Gillian M. McCombs, "The Opportunity Costs of Faculty Status for Academic Librarians," College \& Research Libraries 56 (May 1995): 258.

25. Robert J. Branham, "Roads Not Taken: Counterplans and Opportunity Costs," Argumentation and Advocacy 25 (spring 1989): 254.

26. See Association of College and Research Libraries, "Statement on the Certification and Licensing of Academic Librarians" (Chicago: ACRL, 1989); and Council of Graduate Schools, A Policy Statement: The Doctor of Philosophy Degree (Washington, D.C.: Council of Graduate Schools, 1990).

27. Crowley, "Draft Research Model of the Research University Library," $125-58$.

28. For a consideration of failed technical solutions in situations requiring changes in values, see Garrett Hardin, "The Tragedy of the Commons," Science 162, no. 3859 (13 Dec. 1968): 124348.

29. See Rogers, Diffusion of Innovations, 209; and "The Self-Fulfilling Prophecy," in Merton's Social Theory and Social Structure, 475-90.

30. See Jonathan R. Cole, "Balancing Acts: Dilemmas of Choice Facing Research Universities," Daedalus 122 (fall 1993): 1-36; and Donald Kennedy, "Making Choices in the Research University," Daedalus 122 (fall 1993): 127-56.

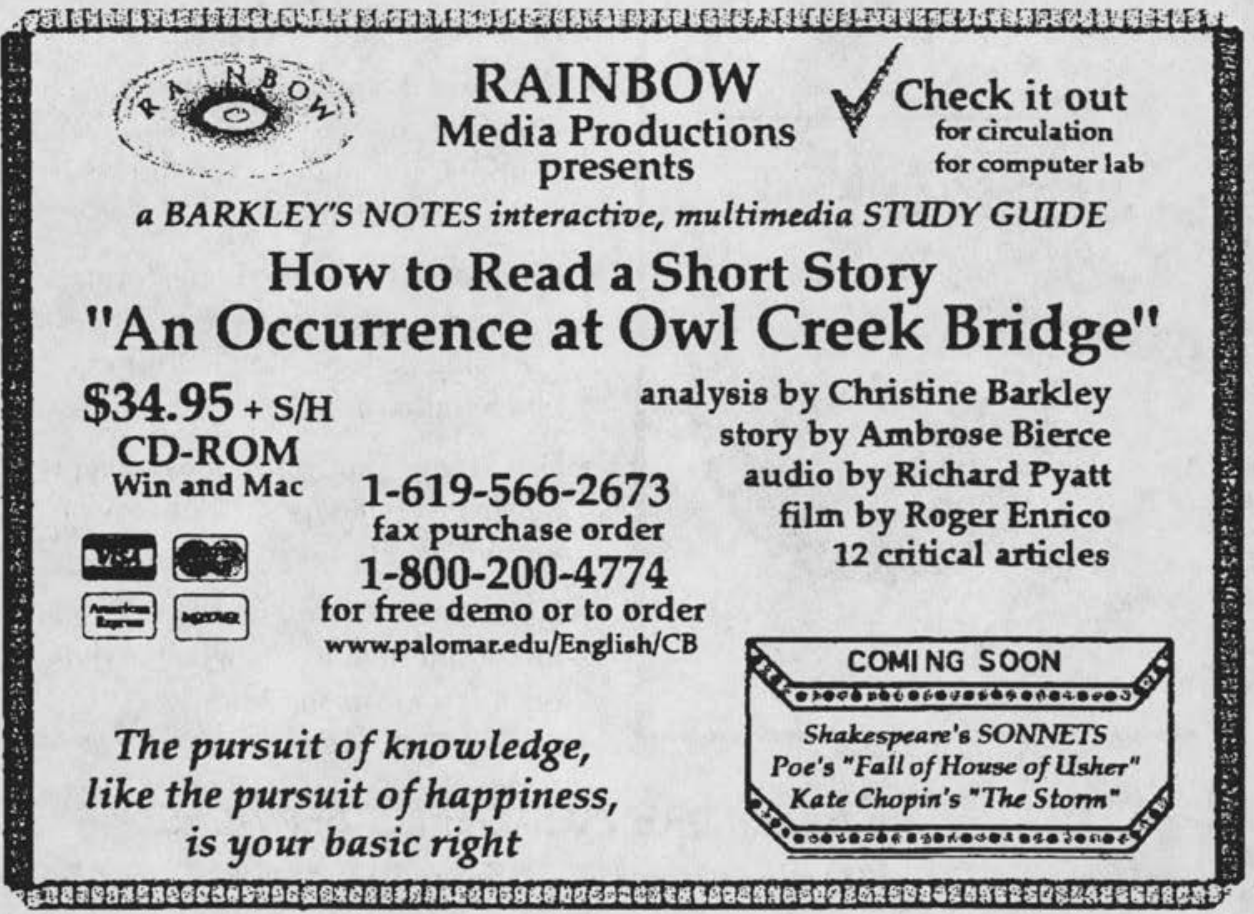




\section{The State \\ of the Art}

...working

smart

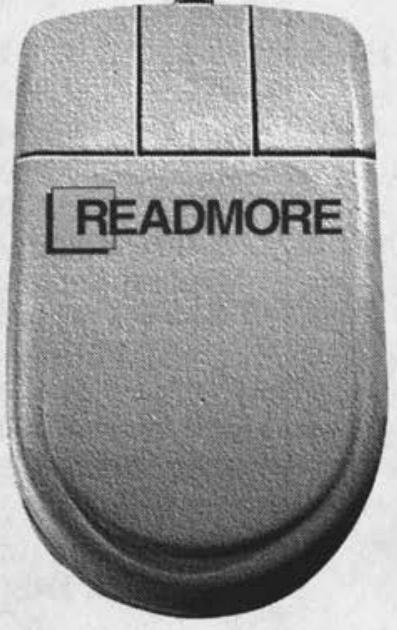

Leaders in the Information

Industry providing subscription services, article delivery and library automation software.

- REMo Mouse driven serials management system.

- Ross Online ordering, claiming and searching of journal and publisher databases.

- Renewal Express PC-based system to analyze current serials holdings and plan for the future collection development.

- Financial Planner Lotus formatted worksheet to analyze previous spending history and plan future budget allocations.

- UnCover The fastest most comprehensive service for fax delivery of journal articles available today.

- BACKSERv An Internet list devoted to the informal exchange of serial back issues among libraries.

\section{Readmore ACademic Services}

700 Black Horse Pike, Suite 207

Blackwood, NJ 08012

Phone: 1-800-645-6595

Fax: 609-227-8322 